\title{
Ewa Szabela-Pasierbińska
}

Uniwersytet Ekonomiczny we Wrocławiu

e-mail: ewa.szabela@ue.wroc.pl

ORCID: 0000-0002-1170-8448

\section{OCENA PROGRAMU OPERACYJNEGO ROZWÓJ POLSKI WSCHODNIEJ 2007-2013}

\section{ASSESSMENT OF THE OPERATIONAL PROGRAMME DEVELOPMENT OF EASTERN POLAND 2007-2013}

DOI: $10.15611 /$ sie.2018.2.03

JEL Classification: I25

Streszczenie: Celem artykułu była ocena efektów działań podjętych w ramach Programu Operacyjnego Rozwój Polski Wschodniej 2007-2013 w województwach Polski Wschodniej w dziedzinie edukacji i rozwoju. W badaniach posłużono się metodami taksonomicznymi - przeprowadzono analizę skupień oraz wyznaczono miarę syntetyczną, jaką był wskaźnik względnego poziomu rozwoju (BZW) dla lat 2007 (początek Programu) oraz 2014 (po zakończeniu Programu). W obu podejściach wykorzystano wskaźniki ładu społecznego dotyczące dziedziny edukacji i rozwoju. Wyniki przeprowadzonych badań pokazały, że Program Operacyjny Rozwój Polski Wschodniej 2007-2013 nie przyniósł istotnych zmian w badanej dziedzinie - województwa Polski Wschodniej (oprócz lubelskiego) w 2014 r. nadal zajmowały ostatnie miejsca w Polsce, zaobserwowano nawet pogorszenie ich sytuacji w stosunku do $2007 \mathrm{r}$.

Słowa kluczowe: Polska Wschodnia, kapitał ludzki, ład społeczny, analiza wielowymiarowa.

Summary: The aim of the article was to assess the effects of measures taken under the Operational Programme Development of Eastern Poland 2007-2013 in the regions of Eastern Poland in the field of education and development. In the research, taxonomic methods were used: cluster analysis was performed and a synthetic measure was determined which was the indicator of the relative level of development (BZW) for 2007 (the beginning of the Programme) and for 2014 (after the end of the Programme). In both approaches, socio-economic indicators related to education and development were used. The results of the conducted analyses have shown that in synthetic terms, the Operational Programme Development of Eastern Poland 2007-2013 did not bring significant changes in the studied area. Voivodships of Eastern Poland (apart from the Lublin province) in 2014 still occupied the last places in Poland and even the deterioration of their situation in relation to 2007 was observed.

Keywords: Eastern Poland, human capital, social order, multivariate analysis. 


\section{Wstęp}

Makroregion Polski Wschodniej, obejmujący województwa: lubelskie, podlaskie, podkarpackie, świętokrzyskie i warmińsko-mazurskie, jest najsłabiej rozwiniętym obszarem zarówno Polski, jak i Unii Europejskiej. Podniesienie poziomu rozwoju społeczno-gospodarczego tego makroregionu jest jednym z głównych aspektów, jakie brane są pod uwagę $\mathrm{w}$ polityce regionalnej Polski - w ramach regionalnych programów operacyjnych oraz Programu Operacyjnego Kapitał Ludzki wyodrębniono znaczącą część unijnych środków finansowych dla biedniejszych województw. Chodzi tu przede wszystkim o Program Operacyjny Rozwój Polski Wschodniej 2007-2013 oraz Program Operacyjny Polska Wschodnia 2014-2020. Pierwszy z wymienionych programów miał wspierać działania mające na celu ,zahamowanie tendencji stagnacyjnych, decydujących o marginalizacji i peryferyjności województw Polski Wschodniej” oraz „wykorzystanie istniejących potencjałów dla jej rozwoju", co w konsekwencji miało doprowadzić do przyśpieszenia rozwoju społeczno-gospodarczego tej części Polski w zgodzie z zasadą zrównoważonego rozwoju. Kluczowymi zagadnieniami branymi pod uwagę w budowaniu nowoczesnej gospodarki miały być „przedsięwzięcia związane m.in. z rozwojem infrastruktury uczelni, wspieraniem innowacji, promocji gospodarczej i współpracy, dokapitalizowaniem funduszy podwyższonego ryzyka, a także rozbudową infrastruktury społeczeństwa informacyjnego"2.

Trwający obecnie Program Operacyjny Polska Wschodnia 2014-2020 skupia się na trzech szansach rozwojowych, które w największym stopniu mogą przyczynić się do poprawy pozycji rozwojowej i konkurencyjnej makroregionu3:

- podnoszeniu poziomu innowacyjności makroregionalnej gospodarki, bazującym na endogenicznych wiodących specjalizacjach gospodarczych;

- aktywizacji zasobów pracy i podniesieniu jakości kapitału ludzkiego i społecznego;

- zbudowaniu intensywnych powiązań społeczno-gospodarczych z lepiej rozwiniętym otoczeniem, dla których warunkiem niezbędnym jest zintegrowana i efektywna infrastruktura powiązań komunikacyjnych zewnętrznych i wewnętrznych oraz rozbudowana i zmodernizowana infrastruktura elektroenergetyczna.

W obu Programach zwraca się szczególną uwagę na istotną rolę czynników endogenicznych, które stanowiąc wewnętrzny potencjał rozwojowy badanych województw w połączeniu z zasileniem kapitałowym z zewnątrz, przyśpieszają procesy rozwojowe, transformację oraz konwergencję słabiej rozwiniętych regionów. Jednym z kluczowych czynników endogenicznych jest kapitał ludzki. Zarówno w Stra-

${ }^{1}$ Program Operacyjny Rozwój Polski Wschodniej 2007-2013. Narodowe Strategiczne Ramy Odniesienia 2007-2013. Szczegółowy opis osi priorytetowych, 2014, http://porpw.parp.gov.pl/files/112/146/405/19982.pdf (2.12.2018).

2 Tamże.

${ }_{3}^{3}$ Program Operacyjny Polska Wschodnia 2014-2020, 2018, https://www.polskawschodnia.gov. pl/media/56702/POPW_26042018_wersja_jednolita.pdf (2.12.2018). 
tegii Kapitału Ludzkiego 20204, jak i w Strategii Kapitału Społecznego 2011-20205 podkreśla się, iż rozwój tego kapitału warunkuje przejście od kapitału adaptacji i przetrwania do kapitału rozwojowego, który sprzyja poprawie warunków życia i dobrostanu obywateli. Wysoka jakość kapitału ludzkiego warunkuje zrównoważony rozwój społeczeństwa, potrafi sprostać zmieniającym się warunkom na rynku pracy oraz wymaganiom związanym z budową gospodarki opartej na wiedzy w ramach społecznych zasad zrównoważonego rozwoju - ładu społecznego. Ład społeczny, który definiowany jest jako „stan funkcjonowania i przebiegu zachowania jednostek, zapewniający istnienie, trwanie i rozwój zbiorowości jako całości”, uznawany jest często za nadrzędny w całej istocie ładu zintegrowanego (w którym należy uwzględnić jeszcze ład gospodarczy i ład środowiskowy) z uwagi na to, iż główny nacisk w zasadach tego ładu kładzie się na kategorie jakości życia ${ }^{7}$. Postuluje się w nich m.in. rozwój kapitału ludzkiego poprzez wspieranie w dziedzinie edukacji i nieograniczaniu przepływu, przyswajania i przetwarzania informacji.

\section{Stan kapitału ludzkiego w województwach Polski Wschodniej - przegląd literatury}

Obszerna analiza pozycji województw Polski Wschodniej na tle pozostałych województw Polski pod względem społecznym została zaprezentowana w pracy Kapitat intelektualny $w$ rozwoju regionów Polski Wschodniej. . M. Wosiek bada potencjał rozwojowy tkwiący w zasobach własnych wschodnich województw, analizując zespół czynników składających się na strukturę kapitału intelektualnego, który nawiązuje do ujęcia wiedzy jako zasobu i czynnika produkcji. Autorka obejmuje analizą lata 1999-2009, biorąc pod uwagę wskaźniki dotyczące demografii, wykształcenia, edukacji (szkoły wyższe, nauczyciele akademiccy), zaufania społecznego, nakładów na badania i rozwój, poziomu wynalazczości, wykorzystania technologii informacyjno-komunikacyjnych. Do oceny poziomu rozwoju województw wschodnich oraz ich nasycenia kapitałem intelektualnym wykorzystuje głównie statystyczne metody analizy danych. Bada m.in. korelacje i kształtowanie się tendencji rozwojowych, analizując i oceniając pakiet wskaźników cząstkowych charakteryzujących poszczególne wymiary badanego kapitału. Sięga również po metody taksonomiczne, kon-

${ }^{4}$ Strategia Rozwoju Kapitału Ludzkiego 2020, Załącznik do uchwały nr 104 Rady Ministrów z dnia 18 czerwca 2013 r. (poz. 640), Monitor Polski z 7.08.2013.

${ }^{5}$ Strategia Rozwoju Kapitału Społecznego 2011-2020, Ministerstwo Kultury i Dziedzictwa Narodowego, bip.mkidn.gov.pl (2.12.2018).

${ }^{6}$ M. Burchard-Dziubińska, A. Rzeńca, D. Drzazga, Zrównoważony rozwój - naturalny wybór, Wydawnictwo Uniwersytetu Łódzkiego, Łódź 2014, s. 155.

${ }^{7}$ T. Borys (red.), Wskaźniki zrównoważonego rozwoju, Wydawnictwo Ekonomia i Środowisko, Warszawa-Białystok 2005, s. 317.

${ }^{8}$ M. Wosiek, Kapitat intelektualny w rozwoju regionów Polski Wschodniej, Wydawnictwo Uniwersytetu Rzeszowskiego, Rzeszów 2012. 
struując syntetyczny miernik jako średnią arytmetyczną znormalizowanych, wybranych wskaźników w celu określenia indeksu kapitału intelektualnego. Do zbadania podobieństw pomiędzy wszystkimi województwami Polski co do struktury kapitału M. Wosiek wykorzystuje analizę skupień. Podsumowując badania zaprezentowane w pracy, autorka wnioskuje, iż w Polsce Wschodniej zachodzą zbyt wolno przekształcenia w obszarze kapitału intelektualnego, którego niskie zasoby ograniczają możliwość nadrabiania dystansu rozwojowego pomiędzy województwami wschodnimi a pozostałymi województwami Polski, co oznacza, że województwa Polski Wschodniej ,nie są gotowe do tego, by budować swoją konkurencyjność w oparciu o kapitał intelektualny".

Ocenę województw Polski Wschodniej można również znaleźć w Regionalnym zróżnicowaniu rozwoju ekonomicznego Polski ${ }^{10}$ pod redakcją M. Trojaka. Przedmiotem zainteresowania autorów są przede wszystkim wskaźniki makroekonomiczne pochodzące z lat 2002-2010 (PKB, bezrobocie, płace, inwestycje, dochody). Kapitał ludzki i społeczny został opisany wskaźnikami syntetycznymi (w których m.in. wykorzystano liczbę nauczycieli akademickich jako stymulantę), które posłużyły w dalszych badaniach do wykazania istnienia istotnych statystycznie zależności pomiędzy poziomem kapitału ludzkiego a analizowanymi zmiennymi makroekonomicznymi. Polska Wschodnia i w przypadku tego opracowania okazała się najsłabsza pod względem miar makroekonomicznych, a w województwach: warmińsko-mazurskim, podkarpackim i świętokrzyskim zaobserwowano najniższe poziomy taksonomicznych wskaźników kapitału ludzkiego.

J. Korol we Wskaźnikach zrównoważonego rozwoju w modelowaniu procesów regionalnych ${ }^{11}$ przygląda się województwom polskim m.in. przez pryzmat trzech ładów zrównoważonego rozwoju. W zakresie ładu społecznego rozważa wybrane wskaźniki zrównoważonego rozwoju (w dziedzinie edukacji i rozwoju wybierając liczbę nauczycieli akademickich oraz liczbę studentów szkół wyższych) w $1998 \mathrm{r}$. i w 2003 r. Wyznaczone w oparciu o te wskaźniki statystyczne miary (poziomy minimalne i maksymalne, średnia arytmetyczna, współczynnik zmienności) oraz zastosowany taksonomiczny wskaźnik GDM (uogólniona miara odległości) uwidaczniają negatywną sytuację w sferze zrównoważonego rozwoju w województwach Polski Wschodniej.

Potencjał akademicki brany jest pod uwagę w ocenie województw Polski Wschodniej w redagowanej przez B. Jóźwika i M. Sagana książce Rozwój Polski Wschodniej. Ograniczenia i wyzwania ${ }^{12}$. W rozdziale Miasta wojewódzkie Polski

${ }^{9}$ Tamże, s. 215.

${ }^{10}$ M. Trojak (red.), Regionalne zróżnicowanie rozwoju ekonomicznego Polski, Wydawnictwo Uniwersytetu Jagiellońskiego, Kraków 2013.

${ }^{11}$ J. Korol, Wskaźniki zrównoważonego rozwoju w modelowaniu procesów regionalnych, Wydawnictwo Adam Marszałek, Toruń 2007.

${ }^{12}$ B. Jóźwik, M. Sagan (red.), Rozwój Polski Wschodniej. Ograniczenia i wyzwania, Difin, Warszawa 2012. 
Wschodniej $i$ ich potencjat rozwojowy M. Sagan wskazuje na kapitał ludzki jako jeden z kluczowych endogenicznych czynników rozwoju, który ściśle sprzężony jest z jakością edukacji wyższej i poziomem nauki w danym ośrodku akademickim. Wykorzystując rankingi szkół wyższych „Rzeczpospolitej” w latach 2004, 2009, 2011 (które mierzą prestiż, siłę naukową, umiędzynarodowienie uczelni i warunki studiowania), zauważa, że w badanych latach najlepszym ośrodkiem akademickim Polski Wschodniej był Lublin, a następnie Białystok. Najgorzej w skali Polski Wschodniej i całego kraju wypadły uczelnie w Kielcach i Rzeszowie. Olsztyn sklasyfikowano na trzecim miejscu.

$\mathrm{Na}$ szanse na szybszy rozwój społeczno-gospodarczy województw Polski Wschodniej z wykorzystaniem potencjału kapitału ludzkiego wskazuje się w Uwarunkowaniach i kierunkach rozwoju województw Polski Wschodniej jako regionów słabo rozwiniętych ${ }^{13}$. Autorka, analizując wybrane cząstkowe wskaźniki w 2010 r. (liczba studentów i absolwentów, wydatki na oświatę i wychowanie, poziom wykształcenia, wydatki gospodarstw domowych na edukację), zauważa, że wśród badanych województw nie można jednoznacznie określić najlepszego czy najgorszego regionu ze względu na wyszczególnione cechy. Także na tle kraju województwa Polski Wschodniej nie zawsze (choć często) zajmują pod względem wymienionych cech ostatnie miejsca.

Przegląd literatury pokazał, że województwa Polski Wschodniej odbiegają (są gorsze) od pozostałych województw kraju pod względem jakości kapitału ludzkiego. Autorzy analizowanych opracowań badali województwa wschodnie przed lub w trakcie trwania Programu Operacyjnego Rozwój Polski Wschodniej 2007-2013. Warto zatem zadać pytanie, czy (zakończony już) Program przyczynił się do podniesienia jakości kapitału ludzkiego we wschodnich województwach w Polsce? Czy w latach 2007-2013 podjęto skuteczne działania w zakresie edukacji i szkolnictwa wyższego - czynników wpływających na rozwój wiedzy, umiejętności i kompetencji społecznych w Polsce Wschodniej?

\section{Cel badania, metody badawcze}

Celem artykułu jest ocena efektów działań podjętych w ramach Programu Operacyjnego Rozwój Polski Wschodniej 2007-2013 w województwach Polski Wschodniej w dziedzinie edukacji i rozwoju. Z oceną tego Programu można się spotkać w cyklu artykułów poświęconych porównaniu sytuacji społeczno-gospodarczej ściany wschodniej z resztą Polski, w których autorki S. Bartosiewicz i E. Stańczyk zajęły się jednak głównie wskaźnikami ekonomicznymi. Przenalizowały płace i wydajność pracy ${ }^{14}$, uzasadniały, że przyczyną gorszej sytuacji Polski Wschodniej jest jej rolni-

${ }^{13}$ J. Kudełko, Uwarunkowania i kierunki rozwoju województw Polski Wschodniej jako regionów stabo rozwiniętych, Studia Polskiej Akademii Nauk, t. CLI, Warszawa 2013.

${ }^{14} \mathrm{~S}$. Bartosiewicz, E. Stańczyk, Małe co nieco o sytuacji ściany wschodniej w porównaniu z reszta Polski, Studia i Prace Wydziału Nauk Ekonomicznych i Zarządzania, nr 31/2013, s. 17-29. 
czy charakter ${ }^{15}$, zbadały tempo i poziom rozwoju sytuacji społeczno-gospodarczej mierzonej wskaźnikami innowacyjności ${ }^{16}$. Autorki w swych badaniach posłużyły się wybranymi wskaźnikami, które z kolei uporząakowane w postaci szeregów czasowych zostały poddane m.in. ilościowej analizie pod względem występowania trendów. Z badań zaprezentowanych w tych publikacjach wynika, że ściana wschodnia nie stała się regionem doganiającym resztę kraju - efekty działań Programu są praktycznie niewidoczne.

W niniejszym opracowaniu efekty działań podjętych w ramach Programu zostały zbadane - jak już wspomniano - w zakresie podnoszenia jakości kapitału ludzkiego w województwach Polski Wschodniej w dziedzinie edukacji i rozwoju. W tym celu posłużono się charakterystykami z tej dziedziny, branymi pod uwagę podczas pomiaru wskaźnikowego w ładzie społecznym ${ }^{17}$. Wskaźniki analizowano w dwóch latach - w pierwszym roku Programu, tj. w 2007 r., oraz po zamknięciu programu, tj. w 2014 r.

W pierwszej kolejności wykorzystano analizę skupień (taksonomię), która umożliwia ,pogrupowanie obiektów zbioru danych w rozłączne grupy (skupienia) spójne wewnętrznie i jak najbardziej zróżnicowane pomiędzy sobą"18. Metody tej analizy stosuje się wtedy, kiedy nie dysponuje się żadnymi hipotezami a priori prowadzone badania są $\mathrm{w}$ fazie eksploracyjnej ${ }^{19}$. Analiza skupień obejmuje kilka etapów, w których dokonuje się wyboru obiektów oraz zmiennych, które bardzo często się normalizuje $\mathrm{e}^{20}$; wybiera się miarę odległości pomiędzy obiektami oraz metodę grupowania $^{21}$; wizualizuje się i ocenia wyniki grupowania ${ }^{22}$.

Uzupełnieniem analizy skupień było zastosowanie wskaźnika względnego poziomu rozwoju (BZW). Jest to metoda porządkowania liniowego obiektów, wykorzystująca ideę metody sum standaryzowanych wartości. Miara ta, nazywana miarą bez wzorca, jest unormowana - jej wartości mieszczą się w przedziale od 0 do 1 .

${ }^{15}$ S. Bartosiewicz, E. Stańczyk, Kontynuacja rozważań na temat wybranych aspektów sytuacji społeczno-gospodarczej ściany wschodniej w porównaniu z reszta Polski w latach 2003-2011, Studia i Prace Wydziału Nauk Ekonomicznych i Zarządzania, nr 36/2014, s. 159-177.

${ }^{16}$ S. Bartosiewicz, E. Stańczyk, Wybrane aspekty sytuacji społeczno-gospodarczej ściany wschodniej w porównaniu z resztą Polski w latach 2004-2013. Część trzecia, Studia i Prace Wydziału Nauk Ekonomicznych i Zarządzania, nr 45/2 2016, s. 121-132.

${ }^{17}$ Por. T. Borys (red.), wyd. cyt., s. 323-324.

${ }_{18} \mathrm{~J}$. Korzeniewski, Metody selekcji zmiennych $w$ analizie skupień, Wydawnictwo Uniwersytetu Łódzkiego, Łódź 2012.

${ }^{19}$ A. Stanisz, Przystępny kurs statystyki z zastosowaniem STATISTICA PL na przykładach z medycyny, t. 3: Analizy wielowymiarowe, Wydawnictwo StatSoft Polska, Kraków 2007, s. 114.

${ }^{20}$ Więcej w: tamże.

${ }^{21}$ Więcej w: A. Balicki, Statystyczna analiza wielowymiarowa i jej zastosowania społeczno-ekonomiczne, Wydawnictwo Uniwersytetu Gdańskiego, Gdańsk 2013, s. 215, 291.

${ }^{22}$ Więcej w: J. Pociecha, B. Podolec, A. Sokołowski, K. Zając, Metody taksonomiczne w badaniach społeczno-ekonomicznych, PWN, Warszawa 1988, s. 73. 
Im wartość bliższa 1, tym obiekt lepszy według przyjętego kryterium ogólnego. Do wyznaczenia wskaźnika BZW stosuje się następujące wzory²3:

$$
\begin{gathered}
W_{i}=\frac{\sum_{j=1}^{k} z_{i j}}{\sum_{j=1}^{k} \max _{i}\left\{z_{i j}\right\}}, \\
z_{i j}=x_{i j}^{*}+\left|\min _{i}\left\{x_{i j}^{*}\right\}\right|, \\
x_{i j}^{*}=\frac{x_{i j}-\bar{x}_{j}}{s_{j}},
\end{gathered}
$$

gdzie: $W_{i}$ - wskaźnik względnego poziomu rozwoju BZW dla $i$-tego obiektu; $x_{i j}-$ wartość $j$-tej cechy dla $i$-tego obiektu (zmiennej diagnostycznej) $)^{24} ; \bar{x}_{j}, S_{j}$ - odpowiednio średnia arytmetyczna oraz odchylenie standardowe $j$-tej cechy.

Wskaźnik BZW jest jedną z częściej wykorzystywanych miar syntetycznych w analizie rynku kapitałowego (przy ocenie siły fundamentalnej spółek oraz ich klasyfikacji) ${ }^{25}$, znajduje również swoje zastosowanie w ocenie nieruchomości ${ }^{26}$.

Zastosowanie analizy skupień oraz wyznaczenie wskaźnika względnego poziomu rozwoju wpisuje się w metodologię badania przestrzennego zróżnicowania obiektów wielocechowych ${ }^{27}$. Pierwsza metoda pozwoliła na klasyfikację (grupowanie) badanych obiektów (województw) pod względem ich podobieństwa w zakresie badanych cech. Można było zauważyć, czy województwa Polski Wschodniej wykazują pod względem wybranych zmiennych podobieństwo do województw uznawanych za najlepiej rozwinięte pod względem społeczno-ekonomicznym (mazowieckiego, małopolskiego, dolnośląskiego ${ }^{28}$ ), czy stanowią odrębną grupę, zajmującą odległą pozycję w stosunku do najlepszych regionów Polski.

Konstrukcja syntetycznego wskaźnika umożliwiła określenie konkretnych miejsc pięciu analizowanych województw w swoistym rankingu województw w dziedzinie edukacji i rozwoju. Porównanie wyników analiz uzyskanych dla 2007 r. z wynikami z roku 2014 r. umożliwiło ocenę efektów działań podjętych w ramach Programu Operacyjnego Rozwój Polski Wschodniej 2007-2013 w województwach, którym program był bezpośrednio dedykowany.

${ }^{23}$ T. Grabiński, S. Wydymus, A. Zeliaś, Metody taksonomii numerycznej w modelowaniu zjawisk społeczno-gospodarczych, PWN, Warszawa 1989.

${ }^{24}$ Należy pamiętać, że zmienne muszą mieć charakter stymulant. Należy zatem - kiedy istnieje taka potrzeba - dokonać odpowiedniego przekształcenia pierwotnych zmiennych.

${ }^{25}$ M. Łuniewska, W. Tarczyński, Metody wielowymiarowej analizy porównawczej na rynku kapitałowym, Wydawnictwo Naukowe PWN, Warszawa 2006.

${ }^{26}$ A. Mazur, D. Witkowska, Zastosowanie wybranych mierników taksonomicznych do oceny nieruchomości, Ekonomika i Organizacja Gospodarki Żywnościowej 2006, nr 60, s. 251-258.

${ }^{27}$ Por. A. Młodak, Analiza taksonomiczna w statystyce regionalnej, Difin, Warszawa 2006.

${ }^{28}$ Te województwa w przeanalizowanych w części 2 artykułu pozycjach literatury zajmowały najczęściej pozycje liderów pod względem rozwoju społeczno-gospodarczego w Polsce. 


\section{Opis badania, wyniki}

Jak już wspomniano, T. Borys proponuje, aby dziedzinę edukacji i rozwoju w społecznym ładzie zrównoważonego rozwoju badać w oparciu o 42 wskaźniki. Na potrzeby badania przeanalizowano 32 wskaźniki ${ }^{29}$. Biorąc pod uwagę ich potencjał informacyjny oraz zgodnie $\mathrm{z}$ procedurą doboru zmiennych do analizy skupień $^{30}$, wskaźnikami, które ostatecznie zostały uwzględnione w analizie jako zmienne diagnostyczne, były:

$x_{1}$ - liczba profesorów przypadająca na 1 tys. studentów;

$x_{2}$ - liczba adiunktów przypadająca na 1 tys. studentów;

$x_{3}$ - liczba doktorantów przypadająca na 10 tys. mieszkańców;

$x_{4}$ - udział wydatków na oświatę i wychowanie w wydatkach ogółem budżetów wojewódzkich;

$x_{5}$ - liczba osób w wieku 25-64 lata uczestnicząca w kształceniu lub szkoleniu;

$x_{6}$ - liczba dzieci w placówkach wychowania przedszkolnego przypadająca na 1 tys. dzieci w wieku 3-5 lat.

Wybrano hierarchiczną metodę grupowania - metodę Warda z metryką euklidesową. Rezultaty przeprowadzonej analizy skupień w postaci wyodrębnionych grup województw przedstawione zostały na rys. 1 i 3.

Analizując rys. 1, przedstawiający dendrogram wyznaczony dla 2007 r., można zauważyć, iż na zaznaczonym przerywaną linią poziomie ${ }^{31}$ można wyodrębnić siedem grup województw o podobnym kształtowaniu się wybranych cech (zmiennych). W grupie pierwszej znajdują się województwa opolskie i lubuskie. Województwa: podkarpackie, mazowieckie, łódzkie i lubelskie stanowią odrębne, jednoelementowe grupy, przy czym trzy ostatnie z wymienionych województw są ze sobą w bliskim sąsiedztwie (pod względem badanych cech są do siebie zbliżone). Dwa pozostałe skupienia stanowią województwa: świętokrzyskie, warmińsko-mazurskie, pomorskie, podlaskie i kujawsko-pomorskie oraz województwa: śląskie, wielkopolskie, małopolskie, zachodniopomorskie i dolnośląskie. Można zatem zauważyć, że zakwalifikowanie większości województw Polski Wschodniej do jednego skupienia oznacza ich podobieństwo w dziedzinie edukacji i rozwoju opisanej ostatecznie przez sześć zmiennych diagnostycznych. Województwa podkarpackie i lubelskie zajmują wobec siebie pozycje odległe, co oznacza, iż w badanej dziedzinie województwa te podobne do siebie nie są.

${ }^{29}$ Liczba analizowanych wskaźników zależała od dostępności danych statystycznych w badanych latach we wszystkich województwach Polski. Dane pochodzą z Banku Danych Lokalnych Głównego Urzędu Statystycznego lub zostały wyliczone w oparciu o dane z tego źródła na potrzeby artykułu.

${ }^{30}$ Pomiędzy zmiennymi branymi pod uwagę nie występowała współliniowość; w zmiennych nie występowały obserwacje odstające; zmienne charakteryzowały się istotną zmiennością.

${ }^{31}$ Poziom ten określony został w oparciu o wykres przebiegu aglomeracji pokazującym odległości pomiędzy skupieniami w momencie, gdy były one łączone. Więcej na ten temat znajduje się w: A. Stanisz, wyd. cyt., s. 141-144. 


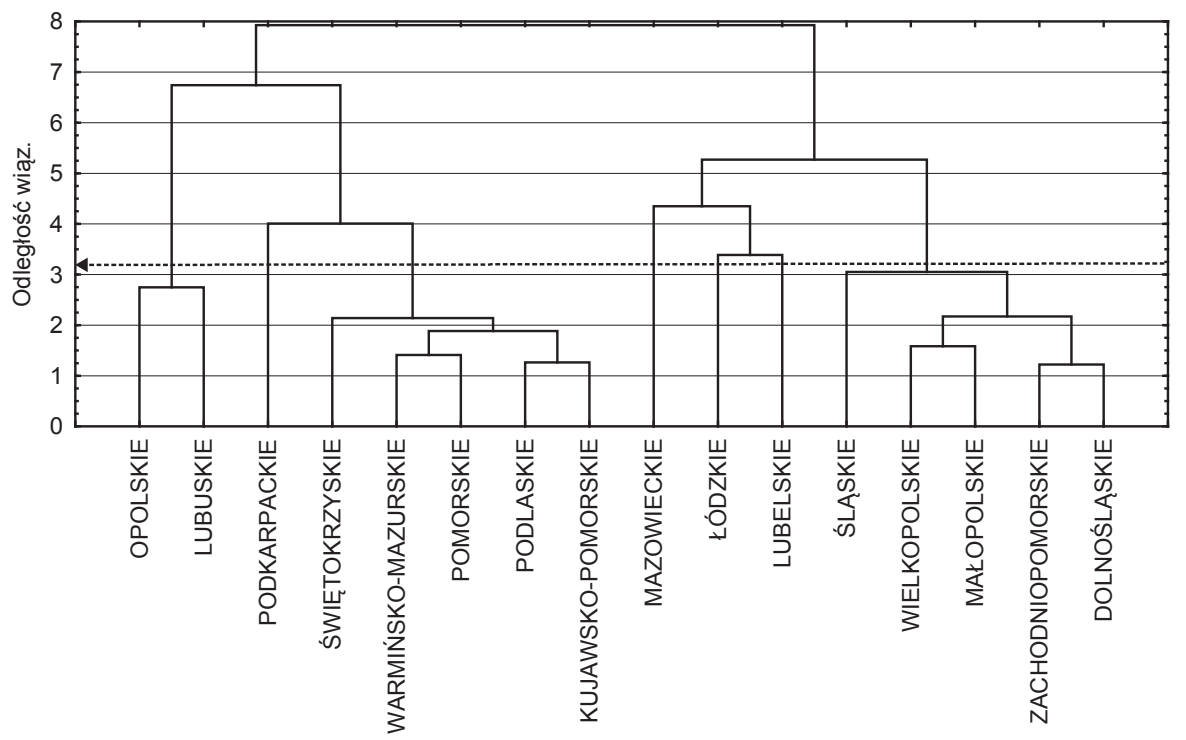

Rys. 1. Dendrogram analizy skupień dla 2007 r. (metryka euklidesowa, metoda Warda) Źródło: opracowanie własne.

Wyniki uzyskane na podstawie analizy skupień dla 2007 r. uzupełniono dodatkowymi informacjami, jakich dostarcza analiza wskaźnika względnego poziomu rozwoju BZW. Jego wartości zaprezentowano na rys. 2.

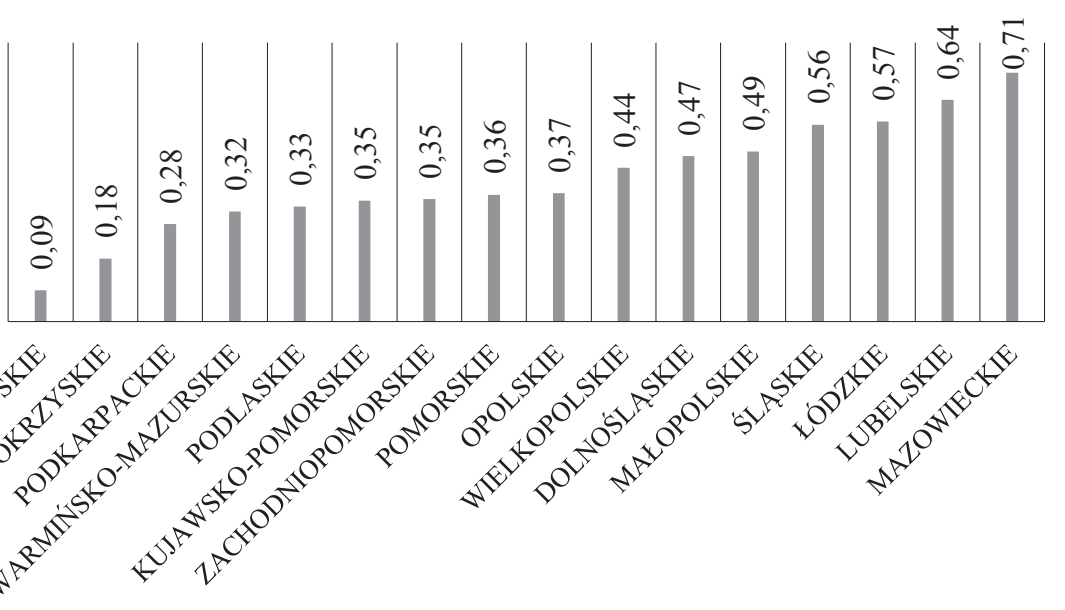

Rys. 2. Wartości wskaźnika BZW dla 2007 r.

Źródło: opracowanie własne. 
Przedstawione na rys. 2 wartości wskaźników BZW pokazały, że cztery województwa Polski Wschodniej (świętokrzyskie, podkarpackie, warmińsko-mazurskie i podlaskie) zajmują ostatnie miejsca pod względem edukacji i rozwoju w Polsce w 2007 r. (gorsze od wymienionych jest tylko województwo lubuskie). Natomiast województwo lubelskie było - obok województwa mazowieckiego - najlepiej rozwiniętym regionem Polski w badanej dziedzinie.

Analizując - analogicznie do rys. 1 - rys. 3 przedstawiający dendrogram wyznaczony dla 2014 r., można zauważyć, iż sytuacja województw wschodnich w porównaniu do 2007 r. nie uległa znaczącej zmianie. Podobnie jak to było w 2007 r., województwa podkarpackie i lubelskie zajmują wobec siebie pozycje odległe. To ostatnie znalazło się w skupieniu razem $\mathrm{z}$ województwem mazowieckim, podkarpackie natomiast tworzy jedno skupienie z województwem opolskim. Województwa warmińsko-mazurskie, podlaskie i świętokrzyskie ponownie zostały zakwalifikowane do jednej grupy (w której znalazły się również zachodniopomorskie i lubuskie). Osobne skupienia stanowią województwa: śląskie, wielkopolskie, łódzkie, kujawsko-pomorskie oraz województwa: pomorskie, małopolskie i dolnośląskie.

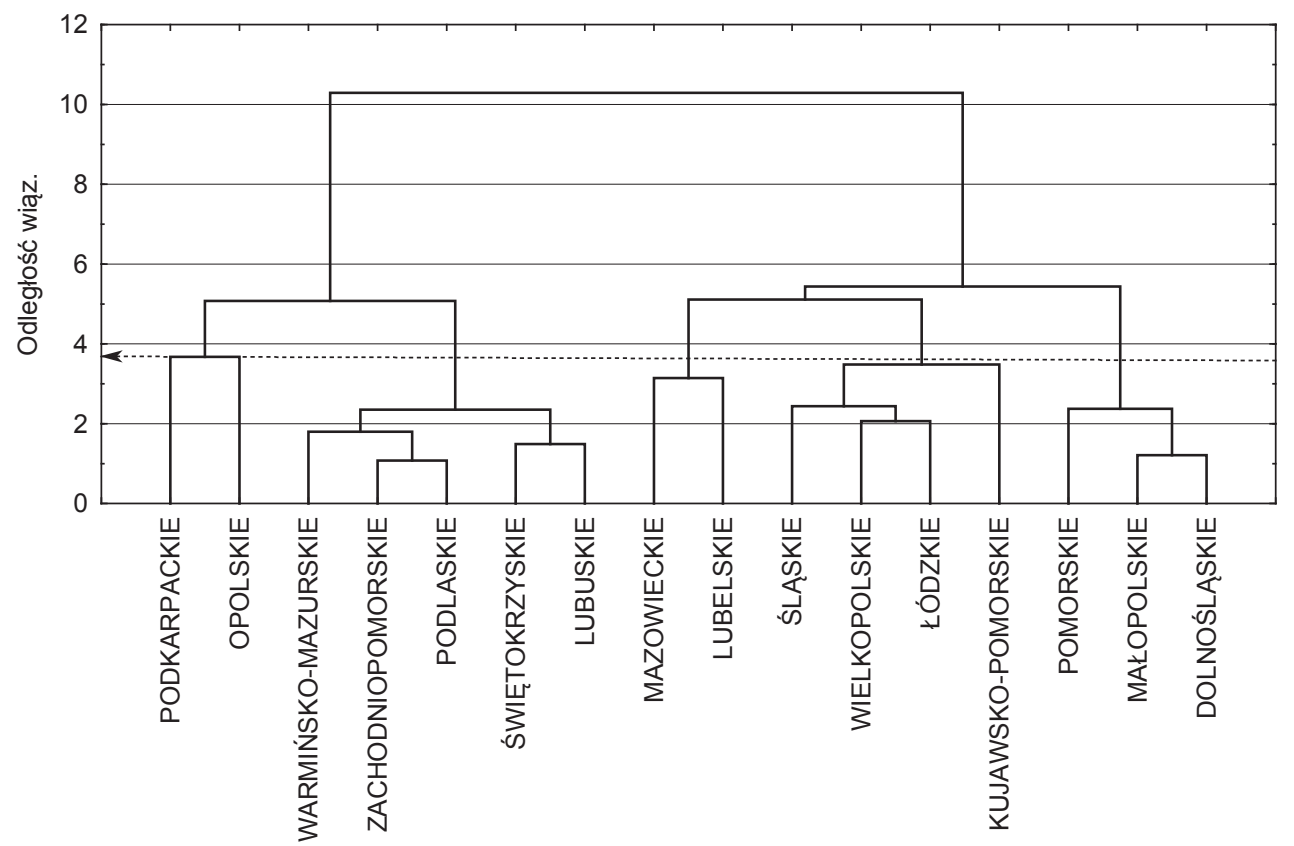

Rys. 3. Dendrogram analizy skupień dla 2014 r. (metryka euklidesowa, metoda Warda) Źródło: opracowanie własne.

Na rysunku 4 przedstawiono wartości syntetycznego wskaźnika BZW w 2014 r. 


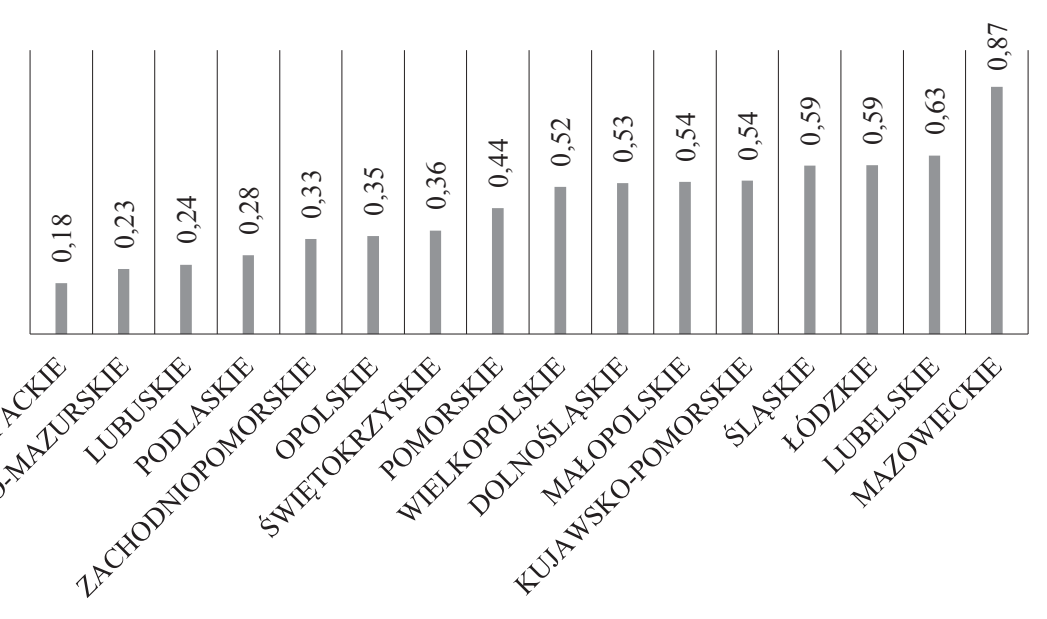

Rys. 4. Wartości wskaźnika BZW dla 2014 r.

Źródło: opracowanie własne.

Analizując wartości wskaźnika BZW w 2014 r., zauważono, że sytuacja większości województw Polski Wschodniej się pogorszyła. Województwa: podkarpackie, warmińsko-mazurskie oraz podlaskie nadal należą do najgorszych województw w Polsce, dodatkowo jednak wyznaczone dla nich wartości wskaźnika BZW były mniejsze (gorsze) niż w 2007 r. Podobnie sytuacja wygląda dla województwa lubelskiego. Chociaż nadal zajmuje ono - obok województwa mazowieckiego - wiodącą pozycję w Polsce, wartość wskaźnika BZW w 2014 r. jest również mniejsza niż w 2007 r. (zwiększył się dystans pomiędzy tym województwem a mazowieckim). Jedynie sytuacja województwa świętokrzyskiego się poprawiła - region ten awansował z 15 miejsca w 2007 r. na 10 miejsce w 2014 r.

\section{Zakończenie}

W artykule przedstawiono wyniki oceny Programu Operacyjnego Rozwój Polski Wschodniej 2007-2013 w dziedzinie edukacji i rozwoju w ujęciu syntetycznym. Podstawą przeprowadzenia badań ilościowych były wskaźniki z dziedziny edukacji i rozwoju, brane pod uwagę w ładzie społecznym zrównoważonego rozwoju. Analiza zarówno skupień, jak i wartości wskaźnika BZW pokazały, że w ujęciu syntetycznym w okresie realizacji Programu nie zaszły istotne, pozytywne zmiany w badanej dziedzinie, a nawet przeciwnie - w większości badanych regionów wystąpiło pogorszenie sytuacji. Województwa wschodnie praktycznie nadal skupiały się w jednej grupie (mowa tu przede wszystkim o województwach: warmińsko-mazurskim, podlaskim i świętokrzyskim), którą - po uwzględnieniu niskich wartości wskaźnika BZW - należy zaliczyć do grupy słabo rozwiniętych regionów pod względem edu- 
kacji i rozwoju. Województwo podlaskie w ocenie syntetycznej wypadło najgorzej, województwo lubelskie w badanym okresie zachowało swoją bardzo dobrą (drugą) pozycję w Polsce. Pozytywne zmiany w badanej dziedzinie zaobserwowano jedynie w województwie świętokrzyskim - z województwa najgorszego spośród pięciu województw w 2007 r. stało się w 2014 r. drugim najlepszym (po województwie lubelskim) województwem Polski Wschodniej.

Program Operacyjny Rozwój Polski Wschodniej 2007-2013 był programem dedykowanym bezpośrednio „najsłabszym” regionom Polski. Wraz z innymi programami realizowanymi na poziomie kraju - m.in. Programem Operacyjnym Kapitał Ludzki, miał się przyczynić do przyśpieszenia rozwoju pięciu województw Polski Wschodniej zarówno pod względem ekonomicznym, jak i społecznym. Zgodnie ze Sprawozdaniem końcowym z realizacji Programu Operacyjnego Rozwój Polski Wschodniej 2007-201332 program wywarł korzystny wpływ na rozwój gospodarczy Polski Wschodniej, zapewniając m.in. podstawy wartościowego kapitału społecznego. W dziedzinie edukacji i rozwoju nastąpiło wzmocnienie potencjału naukowo-badawczego 21 uczelni - zbudowano i zmodernizowano prawie 80 obiektów, z których skorzystał co drugi studiujący w Polsce Wschodniej; otwarto ponad 60 nowych specjalności; dofinansowano zakup 7,2 tys. szt. wyposażenia badawczego na uczelniach i w innych instytucjach badawczych. Studenci i środowisko naukowe, jako jedna z sześciu docelowych grup Programu (pozostałe grupy to: przedsiębiorcy, użytkownicy dróg, turyści, jednostki samorządu terytorialnego, organizacje pozarządowe), w największym stopniu partycypowali w środkach finansowych Programu. Należy zatem mieć nadzieję, że efekty poczynionych w dziedzinie edukacji i rozwoju nakładów w ramach Programu Operacyjnego Rozwój Polski Wschodniej 2007-2013 będą w ujęciu syntetycznym widoczne w kolejnych latach.

\section{Literatura}

Balicki A., Statystyczna analiza wielowymiarowa i jej zastosowania społeczno-ekonomiczne, Wydawnictwo Uniwersytetu Gdańskiego, Gdańsk 2013.

Bartosiewicz S., Stańczyk E., Kontynuacja rozważań na temat wybranych aspektów sytuacji społeczno-gospodarczej ściany wschodniej w porównaniu z reszta Polski w latach 2003-2011, Studia i Prace Wydziału Nauk Ekonomicznych i Zarządzania, nr 36/2014, s. 159-177.

Bartosiewicz S., Stańczyk E., Małe co nieco o sytuacji ściany wschodniej w porównaniu z resztą Polski, Studia i Prace Wydziału Nauk Ekonomicznych i Zarządzania, nr 31/2013, s. 17-29.

Bartosiewicz S., Stańczyk E., Wybrane aspekty sytuacji społeczno-gospodarczej ściany wschodniej w porównaniu z reszta Polski w latach 2004-2013. Część trzecia, Studia i Prace Wydziału Nauk Ekonomicznych i Zarządzania, nr 45/2 2016, s. 121-132.

Borys T. (red.), Wskaźniki zrównoważonego rozwoju, Wydawnictwo Ekonomia i Środowisko, Warszawa-Białystok 2005.

32 www.polskawschodnia.2007-2013.gov.pl/AnalizyRaportyPodsumowania/Strony/default. aspx\#strona=1\&zakladka=2 (6.12.2018). 
Burchard-Dziubińska M., Rzeńca A., Drzazga D., Zrównoważony rozwój - naturalny wybór, Wydawnictwo Uniwersytetu Łódzkiego, Łódź 2014.

Grabiński T., Wydymus S., Zeliaś A., Metody taksonomii numerycznej w modelowaniu zjawisk społeczno-gospodarczych, PWN, Warszawa 1989.

Jóźwik B., Sagan M. (red.), Rozwój Polski Wschodniej. Ograniczenia i wyzwania, Difin, Warszawa 2012.

Korol J., Wskaźniki zrównoważonego rozwoju w modelowaniu procesów regionalnych, Wydawnictwo Adam Marszałek, Torun 2007.

Korzeniewski J., Metody selekcji zmiennych w analizie skupień, Wydawnictwo Uniwersytetu Łódzkiego, Łódź 2012.

Kudełko J., Uwarunkowania i kierunki rozwoju województw Polski Wschodniej jako regionów słabo rozwiniętych, Studia Polskiej Akademii Nauk, t. CLI, Warszawa 2013.

Łuniewska M., Tarczyński W., Metody wielowymiarowej analizy porównawczej na rynku kapitałowym, Wydawnictwo Naukowe PWN, Warszawa 2006.

Mazur A., Witkowska D., Zastosowanie wybranych mierników taksonomicznych do oceny nieruchomości, Ekonomika i Organizacja Gospodarki Żywnościowej 2006, nr 60, s. 251-258.

Młodak A., Analiza taksonomiczna w statystyce regionalnej, Difin, Warszawa 2006.

Pociecha J., Podolec B., Sokołowski A.,. Zając K, Metody taksonomiczne w badaniach społeczno-ekonomicznych, PWN, Warszawa 1988.

Program Operacyjny Polska Wschodnia 2014-2020, 2018, https://www.polskawschodnia.gov.pl/media/56702/POPW_26042018_wersja_jednolita.pdf (2.12.2018).

Program Operacyjny Rozwój Polski Wschodniej 2007-2013. Narodowe Strategiczne Ramy Odniesienia 2007-2013. Szczegółowy opis osi priorytetowych, Warszawa 2014, (2.12.2018).

Sprawozdanie końcowe z realizacji Programu Operacyjnego Rozwój Polski Wschodniej 2007-2013, www.polskawschodnia.2007-2013.gov.pl/AnalizyRaportyPodsumowania/Strony/default. aspx\#strona=1\&zakladka=2 (6.12.2018).

Stanisz A., Przystępny kurs statystyki z zastosowaniem STATISTICA PL na przykładach z medycyny, t. 3: Analizy wielowymiarowe, Wydawnictwo StatSoft Polska, Kraków 2007.

Strategia Rozwoju Kapitału Ludzkiego 2020, Załącznik do uchwały nr 104 Rady Ministrów z dnia 18 czerwca 2013 r. (poz. 640), Monitor Polski z 7.08.2013.

Strategia Rozwoju Kapitału Społecznego 2011-2020, Ministerstwo Kultury i Dziedzictwa Narodowego, bip.mkidn.gov.pl (2.12.2018).

Trojak M. (red.), Regionalne zróżnicowanie rozwoju ekonomicznego Polski, Wydawnictwo Uniwersytetu Jagiellońskiego, Kraków 2013.

Wosiek M., Kapitat intelektualny w rozwoju regionów Polski Wschodniej, Wydawnictwo Uniwersytetu Rzeszowskiego, Rzeszów 2012. 